DOI: 10.22630/EIOGZ.2014.107.26

Zeszyty Naukowe Szkoły Głównej Gospodarstwa Wiejskiego

Ekonomika i Organizacja Gospodarki Żywnościowej nr 107, 2014: 69-80

Tomasz Pajewski

Katedra Ekonomiki i Organizacji Przedsiębiorstw

Szkoła Główna Gospodarstwa Wiejskiego w Warszawie

\title{
Programy rolnośrodowiskowe jako forma wspierania ochrony środowiska na terenach wiejskich
}

\section{Wstęp}

Istnieje wiele instrumentów mających zachęcać ludność do ochrony środowiska naturalnego. Jednym z nich jest Krajowy Program Rolnośrodowiskowy, wpisujący się w II oś Wspólnej Polityki Rolnej, tzw. oś środowiskową. O istocie wspierania środowiska naturalnego w Unii Europejskiej świadczyć może fakt, że wszystkie kraje członkowskie posiadają instrumenty odpowiadające polskim programom rolnośrodowiskowym. Należy jednak zauważyć, że ta forma ingerencji środowiskowej dotyczyć będzie obszarów wiejskich, a więc w głównej mierze rolników bezpośrednio oddziałujących na środowisko.

\section{Cele, hipotezy oraz metody badawcze}

Biorąc pod uwagę coraz większe zainteresowanie i wzmożone działania organów ustawodawczych związanych z zachowaniem przyrodniczych walorów obszarów wiejskich, autor przedstawił znaczenie pakietów rolnośrodowiskowych w kontekście ochrony środowiska naturalnego na terenach wiejskich. Ponadto zostały przedstawione efekty ubiegania się o dofinansowanie prośrodowiskowych działań rolników w kontekście tych programów. Realizacja celów badawczych posłużyła weryfikacji hipotezy badawczej, według której ochrona środowiska na terenach wiejskich uzależniona jest od wielkości rekompensat związanych ze zmniejszeniem intensywności produkcji. 
Metody badawcze związane $\mathrm{z}$ weryfikacją postawionej hipotezy obejmowały analizę realizacji pakietów rolnośrodowiskowych (RS) w ramach Programu Rozwoju Obszarów Wiejskich na lata 2007-2013. Ponadto badaniu poddano wartości środków finansowych przeznaczanych na realizację pakietów RS $\mathrm{z}$ uwzględnieniem kierunku zmian $\mathrm{w}$ ubieganiu się o przyznawane płatności rolnośrodowiskowe. W badaniu wykorzystano informacje dotyczące złożonych wniosków oraz wydanych decyzji w ramach działania „Program rolnośrodowiskowy PROW 2007-2013” generowanych przez Agencję Restrukturyzacji i Modernizacji Rolnictwa (ARiMR).

\section{Istota programu rolnośrodowiskowego}

Prawo ochrony środowiska ustanowione w traktacie rzymskim z 1957 roku stało się podstawą prawodawstwa $w$ aspekcie ochrony środowiska $w$ krajach należących do Wspólnoty Europejskiej. Na mocy tego traktatu powstała również Wspólna Polityka Rolna Unii Europejskiej (WPR UE), której głównym celem było wyznaczanie dalekosiężnych celów strategicznych w sektorze rolnym UE. Pierwotnie założenia Wspólnej Polityki Rolnej dotyczyły przede wszystkim zwiększania efektywności rolnictwa. Takie działania doprowadziły do dynamicznego rozwoju obszarów cieszących się korzystnymi warunkami gospodarowania. Jednakże zbyt intensywne wykorzystywanie zasobów naturalnych na tych terenach spowodowało przyspieszenie degradacji zasobów naturalnych oraz stopniowy zanik gospodarki rolnej na obszarach o niekorzystnych warunkach gospodarowania (gleby słabe, obszary górskie) [Niewęgłowska 2003, s. 7].

Rolnictwo na przestrzeni wieków zawsze w istotny sposób wpływało na środowisko przyrodnicze. Związki te mają charakter dwustronny: zasoby środowiska determinują wielkość i kierunki produkcji rolniczej, a gospodarka rolna zmienia zastane ekosystemy, kształtuje krajobraz i wpływa na poszczególne składniki przyrody [Bołtromiuk 2010, s. 104].

Istotny wpływ rolnictwa na środowisko naturalne podkreślają również Kucharczyk i Różańska. Według nich, obserwowana w branży rolniczej intensyfikacja i specjalizacja produkcji rolnej, jak i zaprzestanie gospodarowania niosą za sobą poważne zagrożenia środowiskowe. Wymieniają tu pięć dziedzin, na które ujemnie wpływa gospodarka rolna [Kucharczyk, Różańska 2012, s. 26-38]:

1) ograniczenia bioróżnorodności,

2) zanieczyszczenia wód,

3) zanieczyszczenia powietrza,

4) degradacja gleb,

5) niekorzystne zmiany w krajobrazie. 
Coraz częściej podejmowany przez rolników ujednolicony system produkcji skutkuje znacznymi ograniczeniami bioróżnorodności na polskiej wsi. W celu osiagnnięcia jak największych korzyści z posiadanych zasobów ziemi polscy rolnicy pozbywają się wszelkich przeszkód ograniczających pełne wykorzystanie areału, takich jak naturalne zbiorniki wodne, miedze, zadrzewienia śródpolne. Jak zauważa Niewęgłowska [2005], zwiększanie areału pól uprawnych związane z likwidacją użytków zielonych, jak i zmiana naturalnych i półnaturalnych łąk i pastwisk na intensywne w sposób istotny wpływają na redukcję liczby miejsc będących ostoją rzadkich gatunków flory i fauny.

Te negatywne skutki zbyt intensywnego zagospodarowania obszarów wiejskich spowodowały zmiany w założeniach Wspólnej Polityki Rolnej. Coraz większą wagę zaczęto bowiem przykładać do ochrony bioróżnorodności na terenach wiejskich. Kucharska [2010, s. 9-10] podkreśla, że znaczenie ochrony bioróżnorodności wynika przede wszystkim z konieczności zachowania równowagi w przyrodzie. Stwierdza jednak, że nie da się objąć ścisłą ochroną całej Ziemi, dlatego też powstała idea rozwoju zrównoważonego, która dotyczy ochrony zróżnicowania biologicznego na obszarach niechronionych. Zakłada ona przejście z fazy intensywnego użytkowania zasobów przyrody w fazę spowolnioną.

Jednym z podstawowych działań mających wpłynąć na zmianę orientacji produkcji rolniczej na mniej inwazyjną były polskie programy rolnośrodowiskowe, będące zasadniczą częścią II osi (środowiskowej) Wspólnej Polityki Rolnej. Głównym założeniem realizacji działania rolnośrodowiskowego było ograniczenie intensyfikacji produkcji rolniczej na rzecz gospodarowania ekstensywnego. Promowanie takich zmian było związane z zachowaniem naturalnych walorów przyrodniczych obszarów wiejskich, zmniejszaniem negatywnego wpływu rolnictwa na środowisko i maksymalizacją jego pozytywnego oddziaływania na różnorodność biologiczną i krajobraz obszarów wiejskich [Kucharska 2010, s. 13]. Według Kołodziejczak i Rudnickiego [2012, s. 125], program rolnośrodowiskowy stał się impulsem głównie do rozwoju wielofunkcyjności rolnictwa.

Program rolnośrodowiskowy na lata 2007-2013 stanowiło dziewięć podstawowych pakietów, te zaś dzieliły się na 49 różnych wariantów. Podstawowe pakiety rolnośrodowiskowe obejmowały:

- rolnictwo zrównoważone (1 wariant),

- rolnictwo ekologiczne (12 wariantów),

- ekstensywne trwałe użytki zielone (1 wariant),

- ochronę zagrożonych gatunków ptaków i siedlisk przyrodniczych poza obszarami natura 2000 (10 wariantów),

- ochronę zagrożonych gatunków ptaków i siedlisk przyrodniczych na obszarach Natura 2000 (10 wariantów), 
- zachowanie zagrożonych zasobów genetycznych roślin w rolnictwie (4 warianty),

- zachowanie zagrożonych zasobów genetycznych zwierząt w rolnictwie (4 warianty),

- ochronę gleb i wód (3 warianty),

- strefy buforowe (4 warianty).

Liczba wariantów związana była $\mathrm{z}$ dużym zróżnicowaniem środowiska naturalnego Polski. Tak więc ten silnie rozbudowany program uwzględniający znaczne zróżnicowanie biologiczne na polskiej wsi mógł być wykorzystany przez rolników w zależności od posiadanych zasobów naturalnych. Warianty zawarte $\mathrm{w}$ dziewięciu podstawowych pakietach umożliwiały wprowadzenie działań wspierających środowisko na szeroką skalę. Można zauważyć do jakich obszarów szczególnie narażonych na negatywne działania intensywnej gospodarki rolnej zostały skierowane działania rolnośrodowiskowe. Tak więc program RS promował działania związane z rolnictwem zróżnicowanym, rolnictwem ekologicznym, ekstensywną gospodarką na łąkach i pastwiskach, ochroną zagrożonych gatunków ptaków i siedlisk przyrodniczych na obszarach Natura 2000 oraz poza nimi, zachowaniem zagrożonych zasobów genetycznych roślin i zwierząt w rolnictwie, ochroną gleb i wód oraz utrzymywaniem stref buforowych na terenach podmokłych. Niezmiernie istotny jest również fakt, że rolnik decydujący się na realizację określonego wariantu RS otrzymywał odpowiednią rekompensatę finansową związaną głównie ze zmniejszeniem efektywności gospodarowania wynikającym z ograniczenia intensywności produkcji.

\section{Wyniki badań}

Rozpatrując realizację pakietów rolnośrodowiskowych w Polsce pod kątem wspierania ochrony środowiska naturalnego warto wskazać, na którym miejscu w UE plasuje się nasz kraj pod względem przyznanych środków na to działanie. Tabela 1 przedstawia środki finansowe przeznaczone na płatności w ramach II filaru Wspólnej Polityki Rolnej oraz rolnośrodowiskowe za okres 2007-2013 w krajach Unii Europejskiej.

Według wyników Powszechnego Spisu Rolnego z 2010 roku, w latach 2007-2012 najwięcej środków na płatności w ramach II filaru WPR w przeliczeniu na 1 gospodarstwo otrzymały Czechy (ok. 123 tys. euro). Z kolei najmniejszym beneficjentem tego typu wsparcia była Rumunia (ok. 1,8 tys. euro/gospodarstwo). Przeciętne polskie gospodarstwo w ramach tego filaru otrzymało ok. 8,6 tys. euro. Wartość ta jest wyższa niż średnia wartość dofinansowania na gospodarstwo rolne w grupie państw UE-27 (ok. 7,1 tys. euro/gospodarstwo) i UE-12 
Tabela 1

Środki Unii Europejskiej na płatności rolnośrodowiskowe (2007-2013)

\begin{tabular}{|c|c|c|c|c|c|c|c|c|}
\hline \multirow{3}{*}{ Kraj } & \multicolumn{4}{|c|}{$\begin{array}{l}\text { Wartość płatności z II filaru razem } \\
\text { w latach } 2007-2013^{\star} \text { w przeliczeniu na }\end{array}$} & \multicolumn{4}{|c|}{$\begin{array}{l}\text { Wartość płatności dla programu } \\
\text { rolnośrodowiskowego }{ }^{\star \star} \text { w przeliczeniu na }\end{array}$} \\
\hline & \multicolumn{2}{|c|}{$\begin{array}{l}1 \text { gospodarstwo } \\
\text { rolne }\end{array}$} & \multicolumn{2}{|c|}{1 ha $U R^{*}$} & \multicolumn{2}{|c|}{$\begin{array}{c}1 \text { gospodarstwo } \\
\text { rolne }\end{array}$} & \multicolumn{2}{|c|}{1 ha $U R^{*}$} \\
\hline & euro & $\begin{array}{l}\text { UE-27 = } \\
=100\end{array}$ & euro & $\begin{array}{l}\text { UE-27 = } \\
=100\end{array}$ & euro & $\begin{array}{l}\text { UE-27 = } \\
=100\end{array}$ & euro & $\begin{array}{l}\text { UE-27 = } \\
=100\end{array}$ \\
\hline Austria & 25551,7 & 358,1 & 1333,2 & 258,7 & 12184,3 & 693,6 & 635,7 & 501,1 \\
\hline Belgia & 8521,6 & 119,4 & 297,7 & 57,8 & 2668,7 & 151,9 & 93,2 & 73,5 \\
\hline Bułgaria & 4796,1 & 67,2 & 775,2 & 150,4 & 723,9 & 41,2 & 117,0 & 92,2 \\
\hline Cypr & 4107,3 & 57,6 & 1348,1 & 261,6 & 1016,5 & 57,9 & 333,6 & 263,0 \\
\hline Czechy & 122571,8 & 1717,8 & 804,4 & 156,1 & 38875,9 & 2213,2 & 255,1 & 201,1 \\
\hline Dania & 9766,2 & 136,9 & 163,7 & 31,8 & 4970,3 & 283,0 & 83,3 & 65,7 \\
\hline Estonia & 34985,8 & 490,3 & 729,1 & 141,5 & 10004,1 & 569,5 & 208,5 & 164,3 \\
\hline Finlandia & 32390,9 & 454,0 & 903,0 & 175,2 & 10803,0 & 615,0 & 301,2 & 237,4 \\
\hline Francja & 12357,3 & 173,2 & 229,1 & 44,5 & 2246,8 & 127,9 & 41,7 & 32,8 \\
\hline Grecja & 4220,3 & 59,1 & 890,5 & 172,8 & 808,6 & 46,0 & 170,6 & 134,5 \\
\hline Hiszpania & 7124,5 & 99,8 & 269,9 & 57,6 & 1107,7 & 63,1 & 46,2 & 36,4 \\
\hline Holandia & 6686,8 & 93,7 & 258,3 & 50,1 & 1625,6 & 92,5 & 62,8 & 49,5 \\
\hline Irlandia & 16705,5 & 234,1 & 468,2 & 90,9 & 9791,0 & 557,4 & 274,4 & 216,3 \\
\hline Litwa & 8371,9 & 117,3 & 610,0 & 118,4 & 1490,3 & 84,8 & 108,6 & 85,6 \\
\hline $\begin{array}{l}\text { Luksem- } \\
\text { burg }\end{array}$ & 39146,9 & 548,6 & 687,9 & 133,5 & 11643,3 & 662,9 & 204,6 & 161,3 \\
\hline Łotwa & 11985,5 & 168,0 & 556,4 & 108,0 & 1659,1 & 94,5 & 77,0 & 60,7 \\
\hline Malta & 5871,5 & 82,3 & 6425,3 & 1246,8 & 672,0 & 38,3 & 735,4 & 579,7 \\
\hline Niemcy & 26717,1 & 374,4 & 478,4 & 92,8 & 7302,9 & 415,8 & 130,8 & 103,1 \\
\hline Polska & 8648,6 & 121,2 & 901,9 & 175,0 & 1223,3 & 69,6 & 127,6 & 100,6 \\
\hline Portugalia & 12500,4 & 175,2 & 1040,3 & 201,9 & 1362,6 & 77,6 & 113,4 & 89,4 \\
\hline Rumunia & 1836,9 & 25,7 & 525,1 & 101,9 & 200,9 & 11,4 & 57,4 & 45,3 \\
\hline Słowacja & 78905,5 & 1105,9 & 1018,2 & 197,6 & 13710,1 & 780,5 & 176,9 & 139,5 \\
\hline Słowenia & 11999,5 & 168,2 & 1855,9 & 360,1 & 3 271,3 & 186,2 & 506,0 & 398,8 \\
\hline Szwecja & 25188,5 & 353,0 & 584,0 & 113,3 & 13824,7 & 787,0 & 320,5 & 252,6 \\
\hline Węgry & 6334,2 & 88,8 & 779,6 & 151,3 & 1596,6 & 90,9 & 196,5 & 154,9 \\
\hline $\begin{array}{l}\text { Wielka } \\
\text { Brytania }\end{array}$ & 20262,7 & 284,0 & 286,3 & 55,6 & 11539,5 & 656,9 & 163,0 & 128,5 \\
\hline Włochy & 4957,2 & 69,5 & 625,0 & 121,3 & 1343,8 & 76,5 & 169,4 & 133,5 \\
\hline UE-27 & 7135,3 & 100,0 & 515,3 & 100,0 & 1756,6 & 100,0 & 126,9 & 100,0 \\
\hline UE-15 & 9786,4 & 137,2 & 426,3 & 82,7 & 2904,1 & 165,3 & 126,5 & 99,7 \\
\hline UE-12 & 5081,5 & 71,2 & 748,6 & 145,3 & 867,6 & 49,4 & 127,8 & 100,7 \\
\hline
\end{tabular}

* Dane dotyczące liczby gospodarstw oraz powierzchni UR dla 2010 roku.

**Uwzględniono działania: „Płatności dla obszarów Natura 2000 i płatności związane z dyrektywą 2000/60/WE”, „Płatności rolnośrodowiskowe”, „Płatności z tytułu dobrostanu zwierząt” oraz „Inwestycje nieprodukcyjne”.

Źródło: Gospodarstwa rolne w Polsce na tle gospodarstw Unii Europejskiej - wpływ WPR, red. W. Poczta, Powszechny Spis Rolny 2010, Warszawa 2013, s. 188-190. 
(ok. 5 tys. euro/gospodarstwo). Z tabeli 1 można odczytać, że Polska w okresie programowania 2007-2013 zajmowała 15. pozycję pod względem absorbcji płatności z II filaru WPR w przeliczeniu na gospodarstwo rolne. Analizując wartość tego wsparcia w przeliczeniu na 1 ha UR, największą wartość płatności otrzymała Malta (ok. 6,4 tys. euro/ha UR), a najmniej Belgia (ok. 297 euro/ha UR). Polska, uzyskując ok. 900 euro/ha UR, zajmuje 8. pozycję pod względem pozyskiwania wsparcia z filara środowiskowego. Jednakże jest to wynik o wiele lepszy niż średnia w grupie państw UE-27, UE-15 oraz UE-12. Analizując z kolei dane płatności z samego programu rolnośrodowiskowego, sytuacja polskiego rolnictwa jest mniej optymistyczna. Pod względem wartości płatności na gospodarstwo rolne Polska zajmuje 21. pozycję - ok. 1,2 tys. euro/gospodarstwo i znacząco wynik ten odbiega od średniej unijnej. Jedynie w krajach UE-12 średnia wartość płatności przypadająca na gospodarstwo jest mniejsza. Z kolei w przypadku wartości płatności w przeliczeniu na 1 ha UR Polska zajmuje 17. lokatę - 127,6 euro/ha UR i osiaga średni poziom unijny. Przyznanie takiego dofinansowania na działania prośrodowiskowe stworzyło możliwość rekompensowania rolnikom zmiany kierunku gospodarowania z intensywnego na bardziej korzystny dla środowiska - ekstensywny.

Ważna jest jednak kwestia, że programy rolnośrodowiskowe w latach 2007-2013 były dla rolników dobrowolne. Zatem nie byli oni zobligowani do ochrony środowiska naturalnego w takim kształcie jaki obejmowały programy RS. Środki programów operacyjnych Wspólnej Polityki Rolnej były ukierunkowane na poprawę czterech podstawowych płaszczyzn działania gospodarstw rolnych: środowiska przyrodniczego, struktury agrarno-demograficznej $\mathrm{w}$ rolnictwie, wyposażenia technicznego gospodarstw rolnych oraz sytuacji dochodowej gospodarstw rolnych. Absorpcja środków w kontekście takiego rozdysponowania środków WPR w latach 2002-2010 w ujęciu przestrzennym została przedstawiona na rysunku 1.

Jak wynika z rysunku 1, większość środków w latach 2002-2010 w ramach Wspólnej Polityki Rolnej zostało wykorzystane na poprawę struktury agrarno-demograficznej oraz wyposażenie techniczne gospodarstw rolnych. Ochroną środowiska przyrodniczego zainteresowani byli przede wszystkim mieszkańcy północno-zachodniej części kraju oraz mieszkańcy pojedynczych powiatów południowej oraz południowo-wschodniej Polski.

O ilości środków przeznaczonych na realizację działań prośrodowiskowych w ramach działania rolnośrodowiskowego w poszczególnych województwach świadczą informacje zawarte w tabeli 2.

Największe kwoty płatności $\mathrm{w}$ ramach programu RS otrzymali rolnicy w województwach zachodniopomorskim, wielkopolskim i lubelskim. Najniższą zaś kwotą dofinansowania z tego tytułu charakteryzowały się województwa 


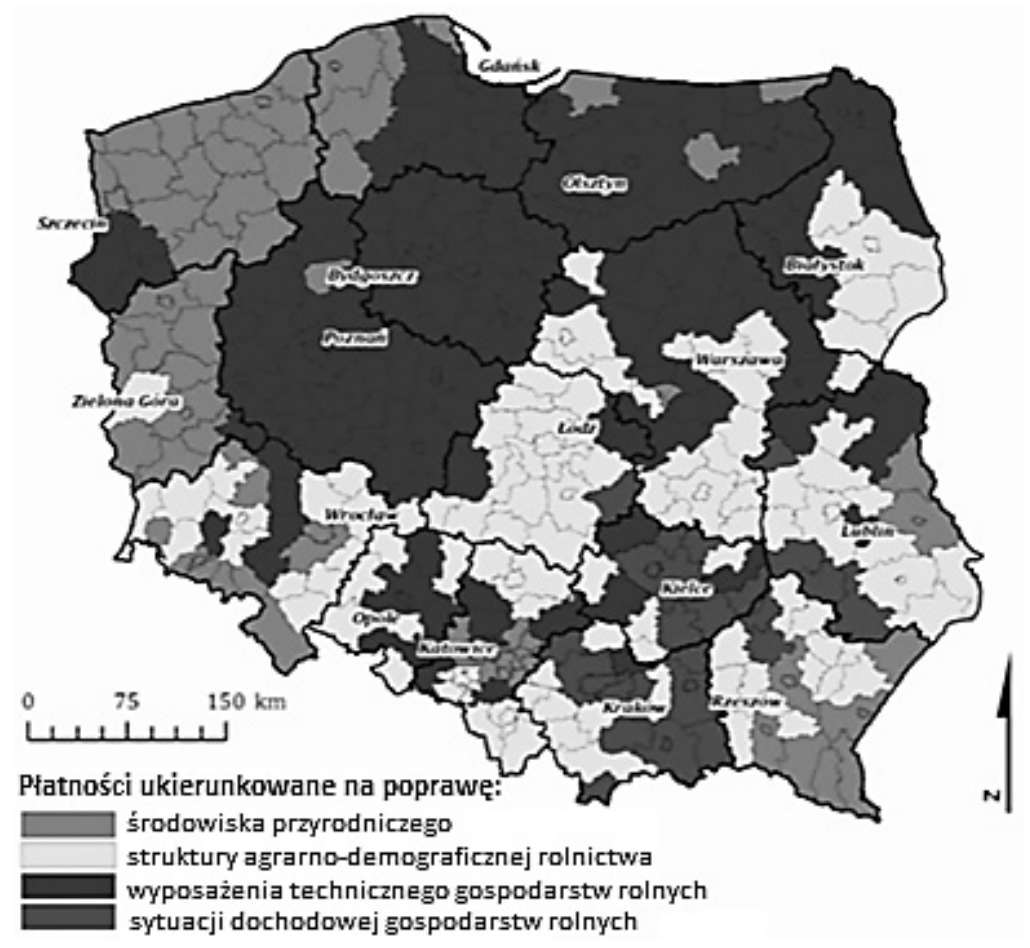

\section{Rysunek 1}

Absorpcja środków programów operacyjnych WPR według przeważającego ukierunkowania ich płatności w latach 2002-2010

Źródło: Powszechny Spis Rolny 2010, Główny Urząd Statystyczny, Warszawa, 2014, s. 455.

łódzkie, śląskie i opolskie. Z kolei w wartości płatności na ha UR czołowe miejsca zajęły województwa małopolskie, mazowieckie i wielkopolskie, a najniższe - opolskie, warmińsko-mazurskie i kujawsko-pomorskie. Należy jednak zauważyć, że nie zawsze kwota udzielonego wsparcia była proporcjonalna do wartości płatności na 1 ha/UR. Dysproporcje te mogą wynikać z faktu, iż Polska jest krajem o dużym zróżnicowaniu pod względem powierzchni gospodarstw. Kolejną przyczyną takiego stanu rzeczy może być duży stopień bioróżnorodności polskiej wsi, co skutkuje możliwością ubiegania się o różne rodzaje wariantów pakietów RS, a co za tym idzie - różnych stawek płatności.

Realizacja pakietów rolnośrodowiskowych nakłada na rolników różnego rodzaju obostrzenia w zakresie intensyfikacji produkcji rolnej. Ograniczenia te związane są głównie z chemicznymi środkami produkcji, bezpośrednio oddziałującymi na grunty rolne. Zmiana w użyciu wybranych środków produkcji została przedstawiona na rysunku 2 . 
Tabela 2

Kwoty wypłacone za realizację programu rolnośrodowiskowego w latach 2007-2012 oraz średnia wypłacona kwota płatności na 1 ha UR

\begin{tabular}{|l|c|c|}
\hline Województwo & Wypłacona kwota ogółem & Wypłacona kwota na 1 ha UR \\
\hline Śląskie & 81565387 & 3971,4 \\
\hline Opolskie & 147308765 & 1937,7 \\
\hline Łódzkie & 153576699 & 3150,0 \\
\hline Małopolskie & 159206643 & 4423,5 \\
\hline Świętokrzyskie & 170984419 & 2803,8 \\
\hline Podkarpackie & 277139523 & 3147,1 \\
\hline Podlaskie & 339196996 & 2765,8 \\
\hline Lubelskie & 343718961 & 2854,8 \\
\hline Dolnośląskie & 352610530 & 2752,3 \\
\hline Kujawsko-pomorskie & 392044178 & 1930,4 \\
\hline Mazowieckie & 432884367 & 4008,2 \\
\hline Pomorskie & 439515562 & 2576,3 \\
\hline Warmińsko-mazurskie & 469032910 & 1828,0 \\
\hline Lubelskie & 523081799 & 2853,1 \\
\hline Wielkopolskie & 600374004 & 3082,6 \\
\hline Zachodniopomorskie & 781008710 & 2997,4 \\
\hline Średnia & 353953091 & 2942,6 \\
\hline
\end{tabular}

Źródło: A. Pawlewicz, P. Bórawski, Realizacja programu rolnośrodowiskowego w Polsce, Roczniki Naukowe SERiA, t. XV, z. 2, s. 275.

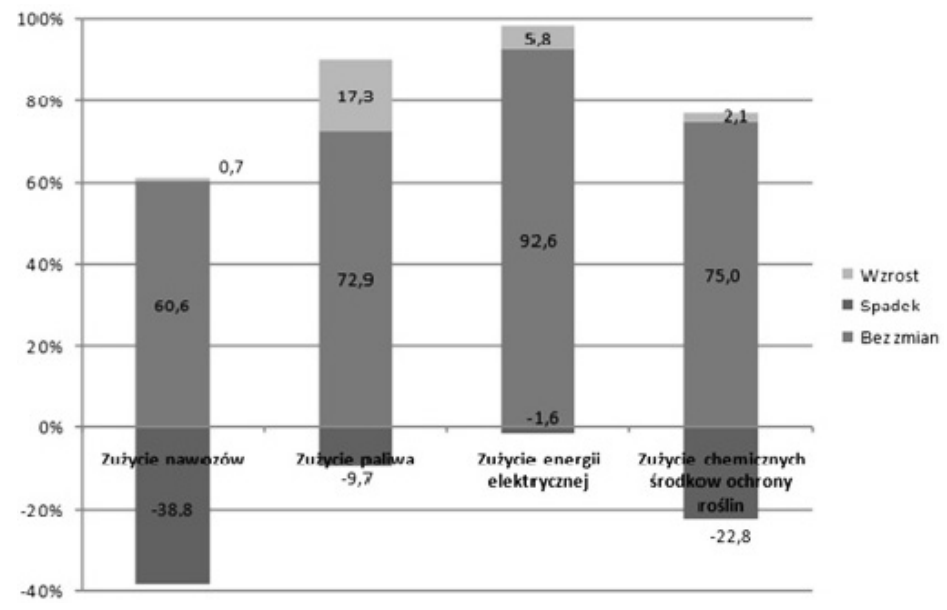

\section{Rysunek 2}

Struktura gospodarstw realizujących programy rolnośrodowiskowe i dokonujących zmian w zużyciu środków produkcji

Źródło: Ocena średniookresowa Programu Rozwoju Obszarów Wiejskich na lata 2007-2013, Raport końcowy, t. II, listopad 2010, s. 307. 
Z badania przeprowadzonego na zlecenie Ministerstwa Rolnictwa i Rozwoju Wsi w 2009 roku wynika, że 38,8\% gospodarstw korzystających z pakietów RS zmniejszyło zużycie nawozów mineralnych, a 22,8\% ograniczyło zużycie chemicznych środków ochrony roślin. Również zużycie paliwa zmniejszyło się w $9,7 \%$, jednakże w $17,3 \%$ badanych gospodarstw nastąpił wzrost zużycia paliwa [Ocena średniookresowa... 2010, s. 307-308].

Zmniejszenie zużycia środków do produkcji rolniczej (rys. 2) niewątpliwie stanowiło pozytywny efekt środowiskowy, np. przez ograniczenie wpływu do gleby różnego rodzaju chemikaliów zawartych w środkach ochrony roślin czy nawozach mineralnych. Należy jednak zauważyć, że zmniejszenie udziału tych czynników produkcji negatywnie oddziaływało na poziom osiaganych plonów. Istotą programów rolnośrodowiskowych jest rekompensowanie rolnikowi utraconych korzyści związanych z rezygnacją z intensywnego gospodarowania na rzecz ekstensywnego - korzystnego dla środowiska naturalnego. Znaczenie dofinansowania w prośrodowiskowych decyzjach rolników zostało zaprezentowane na rysunku 3.

\section{Rysunek 3}

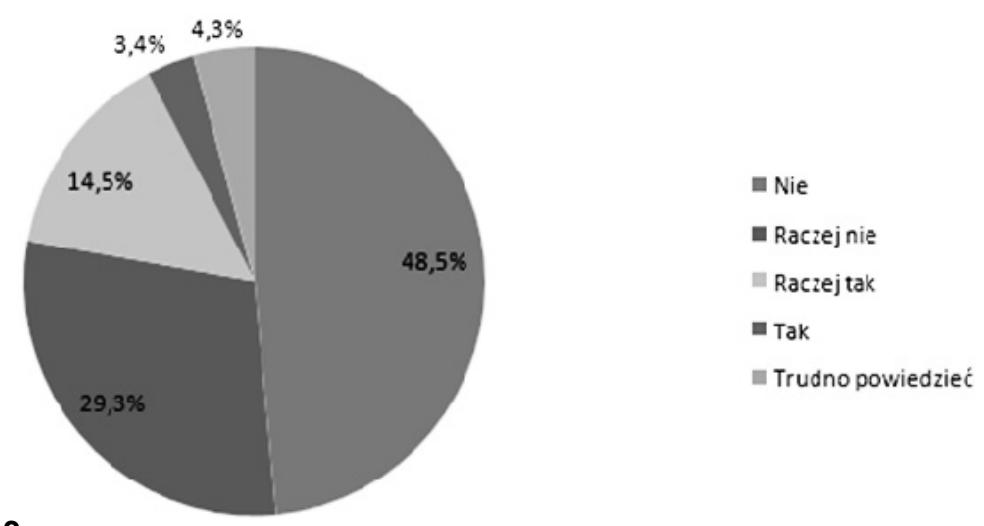

Kontynuacja działań środowiskowych przez rolników bez wsparcia finansowego

Źródło: Ocena średniookresowa Programu Rozwoju Obszarów Wiejskich na lata 2007-2013, Raport końcowy, t. II, listopad 2010, s. 71.

Na podstawie badania wykonanego na zlecenie Ministerstwa Rolnictwa i Rozwoju Wsi w 2009 roku można zauważyć jaki aspekt ma największy wpływ na decyzje prośrodowiskowe podejmowane przez rolników. Według około $80 \%$ badanej grupy beneficjentów programów rolnośrodowiskowych, głównym bodźcem do realizacji działań wspierających ochronę środowiska naturalnego była możliwość otrzymania wsparcia finansowego. Można zakładać, że bez wsparcia finansowego jakie oferują programy rolnośrodowiskowe większość rolników nie zdecydowałaby się na ekstensywny charakter działalności rolniczej w celu 
ochrony środowiska naturalnego. W badaniach ankietowych Kosteckiej i Mroczek wykazano, że rolnicy widzą dla siebie szansę w programach rolnośrodowiskowych, których podstawowym warunkiem jest przestrzeganie zasad Kodeksu Dobrej Praktyki Rolniczej [Kostecka, Mroczek 2007, s. 164-177]. Z kolei z badań Kutkowskiej wynika, że właściciele gospodarstw o większych areałach są bardziej zainteresowani udziałem w tym programie niż właściciele gospodarstw mniejszych. Największe zainteresowanie wystąpiło w grupie gospodarstw o powierzchni od 15 do 30 ha. Rolnicy zapewne dostrzegli, iż wsparcie finansowe związane z tym programem ma charakter dopłat powierzchniowych [Kutkowska 2008, s. 46].

\section{Podsumowanie}

Polska znajduje się w grupie państw Unii Europejskiej, które otrzymały najwięcej środków finansowych na rzecz płatności rolnośrodowiskowych. Polskie programy rolnośrodowiskowe stanowią główny element wspierania ochrony środowiska naturalnego na terenach wiejskich. Duże zróżnicowanie dostępnych pakietów i liczne warianty wsparcia związane są z wysokim poziomem bioróżnorodności polskich obszarów wiejskich. Taka kompozycja programu pozwala na wykorzystanie środków pomocowych przez liczną grupę rolników.

W związku z dużym zróżnicowaniem polskich gospodarstw liczba beneficjentów oraz kwoty pomocy w poszczególnych województwach znacznie się różnią. Według wyników Powszechnego Spisu Rolnego z 2010 roku, w latach 2007-2012 w ramach II filaru przeciętne polskie gospodarstwo otrzymało ok. 8,6 tys. euro. Polska zajmowała 15. pozycję pod względem absorbcji płatności z II filaru WPR w przeliczeniu na gospodarstwo rolne. Analizując wartość tego wsparcia w przeliczeniu na 1 ha UR Polska, uzyskując ok. 900 euro/ha UR, zajmuje 8. pozycję pod względem pozyskiwania wsparcia z filara środowiskowego. $\mathrm{Z}$ kolei w ramach płatności na gospodarstwo rolne z programu rolnośrodowiskowego Polska zajmuje 21. pozycję - ok. 1,2 tys. euro/gospodarstwo. Pod względem wartości płatności w przeliczeniu na 1 ha UR Polska zajmuje 17. lokatę - 127,6 euro/ha UR i osiaga średni poziom unijny.

Największe kwoty płatności $\mathrm{w}$ ramach programu RS otrzymali rolnicy w województwach zachodniopomorskim, wielkopolskim i lubelskim. Najniższą kwotą dofinansowania z tego tytułu charakteryzowały się zaś województwa łódzkie, śląskie i opolskie. W wartości płatności na ha UR czołowe miejsca zajęły natomiast województwa małopolskie, mazowieckie i wielkopolskie, a najniższe - opolskie, warmińsko-mazurskie i kujawsko-pomorskie. 
Należy jednocześnie zauważyć, że realizacja pakietów rolnośrodowiskowych nakłada na rolników różnego rodzaju obostrzenia w zakresie intensyfikacji produkcji rolnej. Prawie co piąty rolnik zdecydował się na ograniczenie zużycia chemicznych środków ochrony roślin. Również zużycie paliwa zmniejszyło się w co dziesiątym gospodarstwie będącym beneficjentem programu rolnośrodowiskowego. O decydującej roli wspomnianego programu w ochronie walorów środowiskowych obszarów wiejskich świadczyć może fakt, iż według około $80 \%$ beneficjentów programów rolnośrodowiskowych głównym bodźcem do realizacji działań wspierających ochronę środowiska naturalnego jest możliwość otrzymania wsparcia finansowego.

Mając na względzie rolę programu rolnośrodowiskowego w rozwijaniu prośrodowiskowych zachowań rolników, należy uznać to działalnie za efektywne narzędzie Wspólnej Polityki Rolnej 2007-2013.

\section{Literatura}

BOŁTROMIUK A., 2010: Ocena wplywu instrumentów Wspólnej Polityki Rolnej na środowisko i zrównoważony rozwój obszarów wiejskich w okresie programowania 2004-2013, [w:] Wpływ funduszy wspótfinansowanych ze środków Unii Europejskiej na rozwój rolnictwa i regionów wiejskich. Raport końcowy, IERiGŻ-PIB, Warszawa.

Gospodarstwa rolne w Polsce na tle gospodarstw Unii Europejskiej - wplyw WPR, red. W. Poczta, Powszechny Spis Rolny 2010, Warszawa 2013.

KOŁODZIEJCZAK A., RUDNICKI R., 2012: Instrumenty Wspólnej Polityki Rolnej ukierunkowane na poprawę środowiska przyrodniczego a planowanie przestrzenne rolnictwa, Acta Scientarium Polonorum, Administratio Locorum 11(2), Wydawnictwo UWM, Olsztyn.

KOSTECKA J., MROCZEK J.R., 2007: Świadomość ekologiczna rolników a zrównoważony rozwój obszarów wiejskich Podkarpacia, Ekonomia i Środowisko 32 (2), s. 164-177.

KUCHARCZYK K., RÓŻAŃSKA E., 2012: Programy rolnośrodowiskowe jako instrument WPR dla ochrony środowiska w UE i Polsce, [w:] Ochrona Środowiska i Zasobów Naturalnych nr 54, s. 26-38.

KUCHARSKA A., 2010: Przewodnik po programie rolnośrodowiskowym, MRiRW, Warszawa.

KUTKOWSKA B., 2008: Realizacja programów rolnośrodowiskowych na terenie Dolnego Ślaska w latach 2004-2006 ze szczególnym uwzględnieniem obszarów o wysokich walorach przyrodniczych, [w:] Ochrona Środowiska i Zasobów Naturalnych nr 35/36, Warszawa, s. 46.

NIEWĘGŁOWSKA G., 2003: Polski Program Rolnośrodowiskowy na tle programów Unii Europejskiej. Komunikaty, raporty, ekspertyzy, IERiGŻ, Warszawa.

NIEWĘGŁOWSKA G., 2005: Zdolność rodzinnych gospodarstw rolnych do realizacji programu rolnośrodowiskowego, Studia i Monografie, IERiGŻ, Warszawa.

Ocena średniookresowa Programu Rozwoju Obszarów Wiejskich na lata 2007-2013, Raport końcowy, t. II, listopad 2010.

PAWLEWICZ A., BÓRAWSKI P., 2013: Realizacja programu rolnośrodowiskowego w Polsce, Roczniki Naukowe SERiA, t. XV, z. 2, s. 275.

Powszechny Spis Rolny 2010, Główny Urząd Statystyczny, Warszawa 2014. 


\title{
Agri-environmentsl programmes as a form of support for environmental protection in rural areas
}

\begin{abstract}
With the entry into the European Union in 2004, Poland is obliged to observe the rules of the Common Agricultural Policy. One of the important areas of this policy is to preserve natural values of the countryside by supporting sustainable agriculture. Thanks to the financial support under the Rural Development Plan (2004-2007) and the Rural Development Programme (2007-2013), Polish farmers received the opportunity to use pro-environmental management methods. This study is devoted to characterizing the main tool to support environmental protection in rural areas of the RDP (2007-2013), namely agri-environmental program. Based on the survey, it was revealed that Poland was one of the countries that received the largest amount of funds for agri-environmental measures. It was also found out that the compensation due to changes in the intensity of production were the main impetus for pro-environmental action.
\end{abstract}

